\title{
International Society of Sports Nutrition position stand: meal frequency
}

\author{
Paul M La Bounty ${ }^{1 *}$, Bill I Campbell ${ }^{2}$, Jacob Wilson ${ }^{3}$, Elfego Galvan ${ }^{4}$, John Berardi ${ }^{5}$, Susan M Kleiner ${ }^{6}$, \\ Richard B Kreider ${ }^{7}$, Jeffrey R Stout ${ }^{8}$, Tim Ziegenfuss ${ }^{9}$, Marie Spano ${ }^{10}$, Abbie Smith $^{8}$, Jose Antonio ${ }^{11}$
}

\begin{abstract}
Position Statement: Admittedly, research to date examining the physiological effects of meal frequency in humans is somewhat limited. More specifically, data that has specifically examined the impact of meal frequency on body composition, training adaptations, and performance in physically active individuals and athletes is scant. Until more research is available in the physically active and athletic populations, definitive conclusions cannot be made. However, within the confines of the current scientific literature, we assert that:

1. Increasing meal frequency does not appear to favorably change body composition in sedentary populations.

2. If protein levels are adequate, increasing meal frequency during periods of hypoenergetic dieting may preserve lean body mass in athletic populations.

3. Increased meal frequency appears to have a positive effect on various blood markers of health, particularly LDL cholesterol, total cholesterol, and insulin.

4. Increased meal frequency does not appear to significantly enhance diet induced thermogenesis, total energy expenditure or resting metabolic rate.

5. Increasing meal frequency appears to help decrease hunger and improve appetite control.

The following literature review has been prepared by the authors in support of the aforementioned position statement.
\end{abstract}

\section{Introduction}

Among adults 20 years or older, living in the United States, $65.1 \%$ are classified as overweight or obese [1]. Furthermore, there is no indication that this trend is improving [1]. Excess body fat has potential physical and psychological health implications as well as potential negative influences on sport performance as well. The various dietary aspects that are associated with overeating and obesity are not well understood [2]. One debated area that is often purported to play a role in body weight/composition changes is meal frequency. The amount and type of calories consumed, along with the frequency of eating, is greatly affected by sociological and cultural factors [3]. Recent evidence suggests that the frequency in which one eats may also be, at least in part, genetically influenced [4]. Infants have a natural desire to eat small meals (i.e., nibble) throughout

\footnotetext{
* Correspondence: paul_la_bounty@baylor.edu

'Dept. of Health, Human Performance and Recreation, Baylor University,

Waco, TX, USA

Full list of author information is available at the end of the article
}

the day [5]. However, as soon as a child reaches a certain age he/she is trained to consume meals in a generally predictable manner [5]. In the modernized world, meal frequency is affected by cultural/social norms as well as an individual's personal beliefs about his/her health or body composition. According to a study utilizing data from the 1987-1988 Nationwide Food Consumption Survey (NFCS), the average daily meal frequency for the 3,182 American adults that completed the study was 3.47 [6]. If meals that consisted of less than or equal to $70 \mathrm{kcals}$, (primarily consisting of tea, coffee, or diet beverages) were excluded from the analysis, the number decreased to 3.12 meals per day. These habits closely mirror the traditional three meals per day pattern (i.e., breakfast, lunch, and dinner) that is common throughout the industrialized world. Although it is often suggested that "nibblers" or "grazers" (i.e., defined in much of the pertinent literature as those that eat smaller meals, but more frequently throughout the day) may be at a metabolic advantage as compared to the "gorgers" (i.e., those that eat fewer, but larger meals), 
the evidence is inconclusive. Some scientists have theorized that consuming a small number of larger meals throughout the day may lead to increased obesity possibly due to increased fat synthesis and storage (i.e., lipogenesis) following a meal [7]. However, there remains debate within the scientific community as the available data is still somewhat equivocal.

In the last few years, studies on the effects of meal frequency have been encouraged among researchers [8]. A majority of this research is justifiably centered on the obesity epidemic. Unfortunately, there is very limited data that has examined the impact of meal frequency on body composition, training adaptations, and performance in physically active individuals and athletes. The primary purpose of this position stand is to discuss the various research findings in which meal/eating frequency has been an independent variable in human studies that assess body composition, various health markers, thermic effect of food (a.k.a. diet induced thermogenesis), energy expenditure, nitrogen retention, and satiety. Also, an attempt has been made to highlight those investigations that have included athletes and physically active individuals in interventions that varied meal frequency eating patterns.

\section{Body Weight and Body Composition Observational Studies}

Several studies utilizing animal models have demonstrated that meal frequency can affect body composition [9-12]. Specifically, an inverse relationship between meal frequency and body composition has been reported [9-12]. Some of the earliest studies exploring the relationship between body weight and meal frequency in humans were published approximately 50 years ago. Table 1 and 2 provide a brief summary of several observational (i.e., cross-sectional, prospective, etc.) human studies that have examined the effect of meal frequency on body weight and/or body composition.

The observational studies listed in Table 1 tend to support [13-19], while investigations in Table 2 refute [2,20-29] the effectiveness of increased meal frequency on body weight and/or body composition. Some of the aforementioned studies [13-15,18,19], if taken at face value, seem to effectively suggest a compelling negative correlation between meal frequency and body composition/body weight. However, aside from obvious genetic differences between subjects, there are other potential confounding factors that could alter the interpretation of these data. Studies in humans that have compared self-reported dietary intake to measured and/or estimated total daily energy expenditure have shown that under-reporting of food is not uncommon in both obese and non-obese individuals [30]. Several investigations have demonstrated that the under-reporting may be significantly greater in overweight and obese individuals [24,30-35]. Additionally, older individuals have also been shown to underreport dietary intake [36]. Under-reporting of dietary intake may be a potential source of error in some of the previously mentioned studies $[13-15,18,19]$ that reported positive effects of increased meal frequency. In fact, in their well written critical review of the meal frequency research from 1964-1997, Bellisle et al. [37] point this out and suggest that classification of subjects' meal frequency and under-reporting of dietary intake can potentially complicate the interpretation of these previously mentioned studies as well as future studies that explore this relationship. Bellisle and colleagues [37] also bring up the valid point of "reverse causality" in which someone who gains weight might skip meal(s) with the hope that they will lose weight. If an individual chooses to do this during the course of a longitudinal study, where meal frequency data is collected, it could potentially alter data interpretation to make it artificially appear that decreased meal frequency actually caused the weight gain [37]. However, even taking reverse causality into account, certain studies listed in Table 1 still demonstrated a positive effect of increased meal frequency on body weight/composition even after accounting for possible under-reporters $[16,17]$ and dieters/restrained eaters [17]. Thus, the potential problem of under-reporting cannot be generalized to all studies that have shown a benefit of increased meal frequency.

Equally important, several studies that initially found a significant inverse relationship between meal frequency and body weight/composition were no longer significant after the investigators adjusted for under-reporters $[22,23]$, dieters/restrained eaters [24], physical activity/ peak oxygen consumption [29], or other various potential confounding variables such as age, energy intake, physical activity, smoking status, etc. [21]. Nevertheless, Ruidavets et al. [17] still demonstrated a significant negative correlation between meal frequency and both BMI and waist-to-hip ratio even after adjusting for under-reporters, and dieters.

Taking all of the observational studies listed in Table 1 and 2 into account, it is difficult to make definitive conclusions about the relationship between meal/eating frequency and body weight/composition. However, when accounting for the effects of under-reporting, exercise, and other confounding variables, the preponderance of the research suggests that increased meal frequency does not play a significant role in decreasing body weight/weight composition.

\section{Experimental Studies}

The majority of experimental studies utilizing meal frequency interventions recruited overweight/obese 
Table 1 Observational Studies Supporting the Effectiveness of Increased Meal Frequency on Weight loss/Fat loss

\begin{tabular}{ll}
\hline $\begin{array}{l}\text { Study } \\
\text { (year) }\end{array}$ & Population \\
\hline Fabry et al. & 379 older males (60-64 yrs) \\
[13] (1964) & \\
Hedja \& & 89 males (30-50 yrs) \\
$\begin{array}{l}\text { Fabry [14] } \\
\text { (1964) }\end{array}$ \\
$\begin{array}{l}\text { Metzner } \\
\text { et al. [15] }\end{array}$ & $\begin{array}{l}\text { (35-69 yrs) } \\
\text { (1977) }\end{array}$
\end{tabular}

Drummond 42 males and 37 females (20-55 yrs) et al. [16] with a BMl from 18-30. (Suspected (1998) under-reporters were excluded from final analysis)

Ruidavets 330 males ( $45-64$ yrs)
et al. [17]
(2002)
Ma et al. 251 males and 248 females ( $20-70$ yrs)
[18] (2003)

Franko et al. 1,209 black and 1,166 white female [19] (2008) school children (9-19 yrs)

\section{Measurements Findings}

Frequency of food intake survey, calculation to determine overweight classification, triceps and subscapular skinfolds, and blood variables

Ingesting $>5$ meals/d, as compared to $<3$ meals/d, significantly improves overweight classification and subcutaneous fat. 2 week diet records along with height, body
weight, and 12 site skinfold thickness

24 hour diet record interview, calculated adiposity index (i.e., calculated using triceps and subscapular skinfold measurements, height, and weight)

The group that ate less than 4 meals/day had a significantly greater body mass and skinfold averages than those that ate $>5$ meals/day.

Adiposity index was inversely related (significantly) to meal frequency in both men and women after adjusting for caloric intake. In summary, as meal frequency increased, overweight classification decreased.

7 day food diary; 7 day activity diary, 48 hour HR monitoring, 4 site skinfold thickness, height, and body weight.

Significant negative correlation between eating frequency and body weight was observed in males, but not females. Eating frequency was significantly correlated with total energy intake in females, but not in males. In both men and women no significant correlations between eating frequency and total energy expenditure were observed.

3 day diet record, estimated physical activity (i.e., leisure, work related, and walking/cycling to work), body mass index, and waist-to-hip ratio

After eliminating under reporters (new sample size $=297$ ) and restrained eaters (new sample size $=243$ ), a significant negative correlation between eating frequency and BMI as well as waist-to-hip ratio was observed.

After adjusting for age, sex, physical activity, education, and total energy intake, participants reporting 4 or more eating episodes per day had a significantly lower risk of developing obesity than those eating 3 or fewer times per day.

Multiple 3-day food diaries taken over several years, height, weight, and self reported physical activity
Girls between 9-19 years old, that ate 3 or more meals per day had significantly lower BMl-for-age Z scores. populations [38-42]. When total daily calories were held constant (but hypocaloric) it was reported that the amount of body weight lost was not different even as meal frequency increased from a range of one meal per day up to nine meals per day [38-42]. Most recently in 2010, Cameron et al. [43] examined the effects of an eight week hypocaloric diet in both obese male and female participants. The subjects consumed either three meals per day (low meal frequency) or three meals plus three additional snacks (high meal frequency). Individuals in both the high and low meal frequency groups had the same caloric restriction $(\sim 700 \mathrm{kcals} /$ day $)$. Both groups lost $\sim 5 \%$ of their initial weight as well as similar decreases in lean mass, fat mass and overall BMI [43]. There were no significant differences between the varying meal frequencies groups in any measure of adiposity [43].

In addition to overweight/obese populations, a few experimental investigations have been conducted in normal weight subjects [44-47]. In relation to improvements in body weight and body composition, the results were similar to those of the overweight/obese trials - no improvements with increasing meal frequencies [44-47].
Even under isocaloric conditions or when caloric intake was designed to maintain the subjects' current body weight, increasing meal frequency from one meal to five meals [47] or one meal to three meals [45] did not improve weight loss. One exception to the non-effectiveness of increasing meal frequency in bodyweight/composition was conducted by Fabry and coworkers [48]. The investigators demonstrated that increases in skinfold thickness were significantly greater when ingesting three meals per day as compared to five or seven meals per day in $\sim 10-16$ year old boys and girls. Conversely, no significant differences were observed in $\sim 6-11$ year old boys or girls [48].

Application to Nutritional Practices of Athletes: Based on the data from experimental investigations utilizing obese and normal weight participants, it would appear that increasing meal frequency would not benefit the athlete in terms of improving body composition. Interestingly, when improvements in body composition are reported as a result of increasing meal frequency, the population studied was an athletic cohort [49-51]. Thus, based on this limited information, one might speculate that an increased meal frequency in athletic populations 
Table 2 Observational Studies Refuting the Effectiveness of Increased Meal Frequency on Weight loss/Fat loss

\begin{tabular}{|c|c|c|}
\hline $\begin{array}{l}\text { Study } \\
\text { (year) }\end{array}$ & Population & Measurements \\
\hline $\begin{array}{l}\text { Dreon et al. } \\
\text { [20] (1988) }\end{array}$ & $\begin{array}{l}155 \text { sedentary, overweight males (i.e., 120- } \\
140 \% \text { of ideal weight) (30-59 yrs) }\end{array}$ & $\begin{array}{l}7 \text { day diet records, physical activity } \\
\text { questionnaires, VO2 max treadmill test, } \\
\text { resting metabolic rate via indirect } \\
\text { calorimetry, hydrostatic weighing, and body } \\
\text { mass. }\end{array}$ \\
\hline
\end{tabular}

Kant et al. 2,580 males and 4,567 females (25-74 yrs) [21] (1995)

Summerbell 187 males and females (divided into 4 et al. [22] different age groups (adolescent, working (1996) age, middle aged, and elderly). Suspected under-reporters were excluded from final analysis

Anderson \& 86 obese and 61 normal weight males Rossner [23] (20-60 yrs) 1996)

298 males and 433 females (16-17 yrs)
Titan et al. [25] (2001)

Bertéus Forslund et al. [26] (2002)

Pearcey and de Castro [27] (2002)

Yannakoulia et al.[28] (2007) women (37-60 yrs)

7 male and 12 female "weight gaining" college students and 7 males and 12 (no age range reported) obese) (24-74 yrs) (Suspected under-
6,890 males and 7,776 females (45-75 yrs)

83 obese and 94 normal weight reference Meal pattern questionnaire and BMI female "weight stable" matched controls

64 pre and 50 post-menopausal women (including normal weight, overweight, and reporters were excluded from analysis) hip ratio (WHR), and self-reported occupational physical activity activity diary, and BMI absorptiometery)
7 day dietary records and $\mathrm{BMI}$

Multiple 24 hour dietary recalls (12 total) and $\mathrm{BMl}$

4 day dietary record and BMI

Food frequency questionnaire, BMI, waist-

7 day food intake diary, 7 day physical

3 day food records, activity records, selfreported physical activity assessment, BMI, WHR, and body composition (dual x-ray
Findings

Meal frequency did not have a significant effect on percent body fat, total weight, fatfree mass, or resting metabolic rate.

When regression analysis accounted for various covariates (i.e., age, energy intake, level of physical activity, smoking status, race, education, baseline $\mathrm{BMI}$, alcohol intake, and level of morbidity), no significant differences between weight change and meal frequency were reported either at baseline or the follow-up.

After removing suspected under-reporters from the analysis, only the adolescent group demonstrated a significant inverse relationship between meal frequency and BMI.

No significant differences in food intake patterns were observed after suspected under-reporters were excluded from final analysis (obese: $\mathrm{n}=23$; normal weight: $\mathrm{n}=$ 44).

Initial analysis in both males and females revealed that there was a significant inverse relationship between feeding frequency and BMI. Removing suspected underreporters still yielded a significant inverse relationship. However, after removing overweight male dieters and under-weight/ normal weight females who believed they were overweight, no significant relationship between meal frequency and $\mathrm{BMI}$ was observed.

After adjusting for confounding variables (i. e., smoking status, age, occupational activity, etc), no consistent significant association in males and females was observed when comparing individuals who ate 1-2 as compared to greater than 6 times per day to BMI or WHR.

The obese women consumed a significantly greater 6.1 meals/day as opposed to the reference group (nonoverweight women) which consumed 5.2 meals/day.

The observed weight gain in the "weight gaining" adults was attributed to the significantly greater intake of fat, carbohydrate, and overall food per meal, but not meal frequency.

There was no association between adiposity indices and eating frequency in pre-menopausal women, but there was a significant positive correlation between body fat percentage and meal frequency in post-menopausal women. Eating frequency was positively correlated with energy intake in both groups of women. 
Table 2 Observational Studies Refuting the Effectiveness of Increased Meal Frequency on Weight loss/Fat loss (Continued)

\begin{tabular}{|c|c|c|c|}
\hline $\begin{array}{l}\text { Howarth } \\
\text { et al. [2] } \\
\text { (2007) }\end{array}$ & $\begin{array}{l}\text { 1,792 younger ( } 20-59 \text { yrs) and } 893 \text { older } \\
\text { (60-69 yrs) males and females (Suspected } \\
\text { under-reporters were excluded from } \\
\text { analysis) }\end{array}$ & Two 24 hour diet records and BMI & $\begin{array}{l}\text { After adjusting for sex, age, smoking status, } \\
\text { ethnicity, income, etc in both age groups, } \\
\text { eating frequency was positively associated } \\
\text { with energy intake. Older and younger } \\
\text { individuals who ate more than three and } \\
\text { six times a day, respectively, had a } \\
\text { significantly higher BMI (i.e., in the } \\
\text { overweight category) than those who ate } \\
\text { less than three and six, respectively. }\end{array}$ \\
\hline $\begin{array}{l}\text { Duval et al. } \\
\text { [29] (2008) }\end{array}$ & $\begin{array}{l}69 \text { non-obese (BMI b/w 20-29 kg/m2), } \\
\text { premenopausal women (48-55 yrs) } \\
\text { (Suspected under-reporters were excluded } \\
\text { from analysis) }\end{array}$ & $\begin{array}{l}7 \text { day food diaries, body composition (dual } \\
\text { x-ray absorptiometry), peak VO2, resting } \\
\text { energy expenditure (REE) via indirect } \\
\text { calorimetry, and physical activity energy } \\
\text { expenditure (PAEE) using an accelerometer }\end{array}$ & $\begin{array}{l}\text { A significant positive correlation was } \\
\text { observed between eating frequency and } \\
\text { total energy intake. There was an initial } \\
\text { significant negative correlation between } \\
\text { eating frequency and each of the following: } \\
\text { BMI, body fat percentage and fat mass. } \\
\text { However, after adjusting for PAEE and peak } \\
\text { oxygen consumption, the associations were } \\
\text { no longer significant. }\end{array}$ \\
\hline
\end{tabular}

may improve body composition. The results of these studies and their implications will be discussed later in the section entitled "Athletic Populations".

\section{Blood Markers of Health}

Reduced caloric intake, in a variety of insects, worms, rats, and fish, has been shown to have a positive impact on health and lifespan [52-54]. Similarly, reduced caloric intake has been shown to have health promoting benefits in both obese and normal-weight adults as well [55]. Some of the observed health benefits in apparently healthy humans include a reduction in the following parameters: blood pressure, C-reactive protein (CRP), fasting plasma glucose and insulin, total cholesterol, LDL cholesterol, and atherosclerotic plaque formation [55]. However, much less has been published in the scientific literature regarding the effects of varying meal frequencies on markers of health such as serum lipids, serum glucose, blood pressure, hormone levels, and cholesterol.

Gwinup and colleagues [56,57] performed some of the initial descriptive investigations examining the effects of "nibbling" versus "gorging" on serum lipids and glucose in humans. In one study [57], five hospitalized adult women and men were instructed to ingest an isocaloric amount of food for 14 days in crossover design in the following manner:

- One large meal per day

- 10 meals per day given every two hours

- Three meals per day

"Gorging" (i.e., one meal per day) led to increases in serum lipids when compared to eating three meals per day. Conversely, 14 days of "nibbling" (i.e., 10 meals per day) led to small decreases in serum lipids such as serum phospholipids, esterified fatty acids, and cholesterol [57]. It is important to point out that this study only descriptively examined changes within the individual and no statistical analyses were made between or amongst the participants [57]. Other studies using obese [58] and non-obese [59] subjects also reported significant improvements in total cholesterol when an isocaloric amount of food was ingested in eight meals vs. one meal [58] and 17 snacks vs. 3 normal meals [59]. In a cross-sectional study which included 6,890 men and 7,776 women between the ages of 45-75 years, it was reported that the mean concentrations of both total cholesterol and LDL cholesterol significantly decreased with increased meal frequency in the general population, even after adjusting for possible confounding variables such as obesity, age, physical activity, and dietary intake [25]. Specifically, after adjusting for confounding variables, the mean total and LDL cholesterol concentrations were $\sim 5 \%$ lower in the individuals that ate more than six times a day as opposed to those only eating once or twice per day [25]. Similarly, Edelstein and colleagues [60] reported that in 2,034 men and women aged 50-89, the individuals that ate greater than or equal to four times per day had significantly lower total cholesterol than those who ate only one to two meals per day. Equally important, LDL concentrations were also lower in those who ate with greater frequency [60].

A more recent study examined the influence of meal frequency on a variety of health markers in humans [45]. Stote et al. [45] compared the effects of consuming either three traditional meals (i.e., breakfast, lunch, and dinner) or one large meal on markers of health. The study was a randomized, crossover study in which each participant was subjected to both meal frequency interventions for eight weeks with an 11 week washout period between interventions [45]. All of the study 
participants ingested an amount of calories needed to maintain body weight, regardless if they consumed the calories in either one or three meals per day. The individuals who consumed only one meal per day had significant increases in blood pressure, and both total and LDL cholesterol [45].

In addition to improvements with lipoproteins, there is evidence that increasing meal frequency also exerts a positive effect on glucose kinetics. Gwinup et al., [5,56] along with others [13], have reported that "nibbling" or increased meal frequency improved glucose tolerance. Specifically, when participants were administered 4 smaller meals, administered in 40 minute intervals, as opposed to one large meal of equal energy density, lower glucose and insulin secretion were observed [61]. Jenkins and colleagues [59] demonstrated no significant changes in serum glucose concentrations between diets consisting of 17 snacks compared to three isocaloric meals per day. However, those that ate 17 snacks per day significantly decreased their serum insulin levels by 27.9\% [59]. Ma et al. [18] point out that the decrease in serum insulin with increased meal frequency may decrease body fat deposition by decreasing lipase enzyme activity.

Contrary to the aforementioned studies, some investigations using healthy men [62], healthy women [63], and overweight women [39] have reported no benefits in relation to cholesterol and triglycerides. Although not all research agrees regarding blood markers of health such as total cholesterol, LDL cholesterol, and glucose tolerance, it appears that increasing meal frequency may have a beneficial effect. Mann [64] concluded in his review article that there seems to be no deleterious effects in regard to plasma lipids or lipoproteins by eating a relatively large number of smaller meals. It is noted, however, that the studies where benefits have been observed with increased meal frequency have been relatively short and it is not known whether these positive adaptations would occur in longer duration studies [64].

Application to Nutritional Practices of Athletes: Although athletic and physically active populations have not been independently studied in this domain, given the beneficial outcomes that increasing meal frequency exerts on a variety of health markers in non-athletic populations, it appears as if increasing meal frequency in athletic populations is warranted in terms of improving blood markers of health.

\section{Metabolism}

Metabolism encompasses the totality of chemical reactions within a living organism. In an attempt to examine this broad subject in a categorized manner, the following sections will discuss the effects of meal frequency on:
- Diet induced thermogenesis (i.e., DIT or also known as the thermic effect of food)

- Resting metabolic rate/total energy expenditure

- Protein Metabolism

\section{Diet Induced Thermogenesis}

It is often theorized that increased eating frequency may be able to positively influence the thermic effect of food, often referred to as diet induced thermogenesis (DIT), throughout the day as compared to larger, but less frequent feedings [65]. Kinabo and Durnin [65] investigated this theory when they instructed eighteen non-obese females to consume either a high carbohydrate-low fat diet consisting of $70 \%, 19 \%$, and $11 \%$ or a low carbohydrate-high fat diet consisting of $24 \%, 65 \%$ and $11 \%$ from carbohydrate, fat and protein, respectively [65]. Each diet was isocaloric and consisted of $1,200 \mathrm{kcals}$. In addition, on two different instances, each participant consumed their meal either in one large meal or as two smaller meals of equal size. The investigators observed no significant difference in the thermic effect of food either between meal frequencies or between the compositions of the food [65].

In two other studies utilizing normal-weight young women [66] and obese children [67] as subjects, it was reported that the ingestion of one large meal significantly increased resting energy expenditure/thermic effect of food as compared to an isocaloric food intake that was ingested in either six [66] or three [67] smaller meals. LeBlanc et al. [61] tested the thermic effect of food in six individuals after consuming four small meals as opposed to one large meal of equal caloric density. Contrary to the earlier findings of Tai et al. [66], post-prandial thermogenesis and fat utilization was greater in the group that consumed the smaller, more frequent meals [61].

Smeets and colleagues [68] conducted a very practical study comparing the differences in consuming either two or three meals a day in normal weight females in energy balance. In this randomized, crossover design in which participants consumed the same amount of calories over a traditional three meal pattern (i.e., breakfast, lunch, and dinner) compared to just two meals (breakfast and dinner) it was demonstrated that there was no significant difference on diet induced thermogenesis when measured over 36 hours in a respiration chamber [68]. However, by consuming three meals per day, fat oxidation, measured over 24 hours using deuterium labeled fatty acids was significantly greater and carbohydrate oxidation was significantly lower when compared to eating just two meals per day [68].

\section{Resting Metabolic Rate/Total Energy Expenditure}

It is argued that the best methodology to study the effects of meal frequency on metabolism utilizes a 
metabolic/respiratory chamber (i.e., a whole body calorimeter). While these conditions are not free living, these types of studies are able to control extraneous variables to a greater extent than other methods. Four investigations utilizing overweight/obese participants $[40,41,69,70]$ and one investigation examining normalweight participants [7] confined the participants to either a metabolic/respiration chamber $[7,41,69,70]$ or a confined metabolic unit [40] and reported that there were no improvements in resting metabolic rate or 24hour energy expenditure due to increasing the number of meals ingested. In each of these investigations, the same number of calories were ingested over the duration of a day, but the number of meals ingested to consume those calories varied from one vs. three and five feedings [40], two vs. three to five feedings [41], two vs. seven feedings $[7,70]$, and two vs. six feedings [69]. The amount of time the participants were confined to the metabolic/respiratory chambers or metabolic unit ranged from a few hours [7] to a few days $[41,69,70]$ to several weeks [40]. From the aforementioned studies examining the effect of meal frequency on the thermic effect of food and total energy expenditure, it appears that increasing meal frequency does not statistically elevate metabolic rate.

\section{Protein Metabolism}

Garrow et al., [40] reported that during a hypocaloric diet lasting three weeks in obese subjects, nitrogen loss was significantly less when the diet consisted of $15 \%$ protein as opposed to $10 \%$ protein. Additionally, nitrogen loss was also significantly less when five versus one meal per day were consumed and protein was kept at a constant 13\% [40]. Equally important, the lowest nitrogen loss occurred when five versus one meal per day were consumed and protein content was $15 \%$ versus $10 \%$ [40]. The authors concluded that the protein content of total caloric intake is more important than the frequency of the meals in terms of preserving lean tissue and that higher protein meals are protein sparing even when consuming low energy intakes [40]. While this study was conducted in obese individuals, it may have practical implications in athletic populations. Specifically, the findings support the idea that frequent feedings with a higher protein content (15\% vs. $10 \%)$ may reduce nitrogen losses during periods of hypocaloric intake.

In contrast to the Garrow et al. findings, Irwin et al. [63] compared the effects of different meal composition and frequency on nitrogen retention. In this study, healthy, young women consumed either three meals of equal size, three meals of unequal size (two small and one large), or six meals (calorie intake was equal between groups). The investigators reported that there was no significant difference in nitrogen retention between any of the different meal frequency regimens [63].

Finkelstein and Fryer [39] also reported no significant difference in nitrogen retention, measured through urinary nitrogen excretion, in young women who consumed an isocaloric diet ingested over three or six meals. The study lasted 60 days, in which the participants first consumed 1,700 kcals for 30 days and then consumed 1,400 kcals for the remaining 30 days [39]. The protein and fat content during the first 30 days was 115 and 50 grams, respectively, and during the last 30 days 106 grams of protein and 40 grams of fat was ingested. The protein content was relatively high (i.e., $\sim 27 \%-30 \%$ of the total daily calories) and may have aided in the nitrogen retention that was observed. Similarly, in a 14-week intervention, Young et al., [42] reported that consuming $1,800 \mathrm{kcals}$ fed as one, three, or six meals a day did not have a significant impact on nitrogen retention in 11 moderately obese, college aged men.

It is important to emphasize that the previous studies were based on the nitrogen balance technique. Nitrogen balance is a measure of whole body protein flux, and may not be an ideal measure of skeletal muscle protein metabolism. Thus, studies concerned with skeletal muscle should analyze direct measures of skeletal muscle protein synthesis and breakdown (i.e., net protein synthesis). Based on recent research, it appears that skeletal muscle protein synthesis on a per meal basis may be optimized at approximately 20 to 30 grams of high quality protein, or 10-15 grams of essential amino acids [71-73]. In order to optimize skeletal muscle protein balance, an individual will likely need to maximize the response on a per meal basis. Research shows that a typical American diet distributes their protein intake unequally, such that the least amount of protein is consumed with breakfast ( 10-14 grams), while the majority of protein is consumed with dinner ( 29-42 grams) [74]. Thus, in the American diet, protein synthesis would likely only be optimized once per day with dinner. This was recently demonstrated by Wilson et al. [75] in a published abstract (utilizing a rodent model). The investigators found that equally distributing protein over three meals (16\% per meal) resulted in greater overall protein synthesis and muscle mass, in comparison to providing suboptimal protein $(8 \%)$ at breakfast and lunch, and greater than optimal protein (27\%) with dinner [75]. In eucaloric meal frequency studies, which spread protein intake from a few (i.e., two to three meals) to several meals (i.e., greater than five meals), the bolus of protein per meal shrinks, which may provide several suboptimal, or possibly non-significant rises in protein synthesis as opposed to a few meals which may maximally stimulate protein synthesis. This is likely the 
case in the previously mentioned study by Irwin et al [63] who compared three $\sim 20$ gram protein containing meals, to six $\sim 10$ gram protein containing meals. Such a study design may negate any positive effects meal distribution could have on protein balance.

With this said, in order to observe the true relationship between meal frequency and protein status, studies likely need to provide designs in which protein synthesis is maximized over five-six meals as opposed to three meals. This was demonstrated by Paddon-Jones and colleagues [76] who found that mixed muscle protein synthesis was $\sim 23 \%$ greater when consuming three large $\sim 850$-calorie meals ( $\sim 23$ g protein, $\sim 127$ g carbohydrate, and $\sim 30 \mathrm{~g}$ fat), supplemented with an additional three small 180-calorie meals containing 15 grams of essential amino acids, as compared to just three 850-calorie meals alone. In summary, the recent findings from the Wilson study [75] combined with the results published by Paddon-Jones et al. [76] suggest that when protein synthesis is optimized, increased feeding frequency may positively impact protein status.

The inattention paid to protein intake in previously published meal frequency investigations may force us to reevaluate their utility. Nutrient timing research $[77,78]$ has demonstrated the importance of protein ingestion before, during, and following physical activity. Therefore, future research investigating the effects of meal frequency on body composition, health markers, and metabolism should seek to discover the impact that total protein intake has on these markers and not solely focus on total caloric intake.

Application to Nutritional Practices of Athletes: Athletic and physically active populations have not been independently studied in relation to increasing meal frequency and observing the changes in resting metabolic rate/total energy expenditure. Considering the data published in overweight/obese and normal weight populations, it appears as if increasing meal frequency would not improve resting metabolic rate/ total energy expenditure in physically active or athletic populations. In regards to protein metabolism, it appears as if the protein content provided in each meal may be more important than the frequency of the meals ingested, particularly during hypoenergetic intakes.

\section{Hunger and Satiety}

Research suggests that the quantity, volume, and the macronutrient composition of food may affect hunger and satiety [79-83]. However, the effect of meal frequency on hunger is less understood. Speechly and colleagues [83] examined the effect of varying meal frequencies on hunger and subsequent food intake in seven obese men. The study participants consumed $1 / 3$ of their daily energy requirement in one single pre-load meal or evenly divided over five meals administered hourly. The meals consisted of 70\% carbohydrate, $15 \%$ protein, and $15 \%$ fat. Several hours after the initial preload meal(s), another meal (i.e., lunch) was given to the participants ad libitum to see if there was a difference in the amount that was consumed following the initial pre-load meal(s). The scientists reported that when the single pre-load meal was given, participants consumed $27 \%$ (i.e., $358 \mathrm{kcals}$ ) more energy in the ad libitum meal than those who ate the multiple pre-load meals [83]. Interestingly, this difference occurred even though there were no significant changes in subjective hunger ratings [83]. Another study with a similar design by Speechly and Buffenstein [84] demonstrated greater appetite control with increased meal frequency in lean individuals. The investigators also suggest that eating more frequent meals might not only affect insulin levels, but may affect gastric stretch and gastric hormones that contribute to satiety [84].

Stote et al. [45] reported that there were significantly greater increases in hunger in individuals eating only one meal as compared to three meals per day. In addition, Smeets and colleagues [68] demonstrated that consuming the same energy content spread over three (i.e., breakfast, lunch, and dinner) instead of two (i.e., breakfast and dinner) meals per day led to significantly greater feeling of satiety over 24 hours [68]. To the contrary, however, Cameron and coworkers [43] reported that there were no significant differences in feelings of hunger or fullness between individuals that consumed an energy restricted diet consisting of either three meals per day or three meals and three snacks. Furthermore, the investigators also determined that there were no significant differences between the groups for either total ghrelin or neuropeptide YY [43]. Both of the measured gut peptides, ghrelin and neuropeptide YY, are believed to stimulate appetite.

Although all research does not agree, it appears that the preponderance of the available research suggests that eating more frequently may decrease hunger and/or food intake at subsequent meals. Even if nothing else was directly affected by varying meal frequency other than hunger alone, this could possibly justify the need to increase meal frequency if the overall goal is to suppress the feeling of hunger.

Application to Nutritional Practices of Athletes: Athletic and physically active populations have not been independently studied in relation to increasing meal frequency and observing the changes in subjective hunger feelings or satiety. Utilizing data from non-athletic populations, increasing meal frequency would likely decrease feelings of hunger and/or food intake at subsequent meals for athletes as well. For athletes wishing to 
gain weight, a planned nutrition strategy should be implemented to ensure hyper-energetic eating patterns.

\section{Athletic Populations}

To date, there is a very limited research that examines the relationship of meal frequency on body composition, hunger, nitrogen retention, and other related issues in athletes. However, in many sports, including those with weight restrictions (gymnastics, wrestling, mixed martial arts, and boxing), small changes in body composition and lean muscle retention can have a significant impact upon performance. Therefore, more research in this area is warranted.

In relation to optimizing body composition, the most important variables are energy intake and energy expenditure. In most of the investigations discussed in this position stand in terms of meal frequency, energy intake and energy expenditure were evaluated in 24-hour time blocks. However, when only observing 24-hour time blocks in relation to total energy intake and energy expenditure, periods of energy imbalance that occurs within a day cannot be evaluated. Researchers from Georgia State University developed a method for simultaneously estimating energy intake and energy expenditure in one-hour units (which allows for an hourly comparison of energy balance) [50]. While this procedure is not fully validated, research has examined the relationship between energy deficits and energy surpluses and body composition in elite female athletes. In a study by Duetz et al. [50], four groups of athletes were studied: artistic and rhythmic gymnasts (anaerobic athletes), and middle-distance and long-distance runners (aerobic athletes). While this study did not directly report meal frequency, energy imbalances (energy deficits and energy surpluses), which are primarily influenced through food intake at multiple times throughout the day were assessed. When analyzing the data from all of the elite female athletes together, it was reported that there was an approximate 800 kilocalorie deficit over the 24-hour data collection period [50]. However, the main purpose of this investigation was to determine energy imbalance not as a daily total, but as 24 individual hourly energy balance estimates. It was reported that the average number of hours in which the withinday energy deficits were greater than $300 \mathrm{kcal}$ was about 7.5 hours, while the average number of hours where the within-day energy surpluses were greater than $300 \mathrm{kcal}$ was about three hours (which makes sense since these athletes were consuming a hypocaloric diet) [50]. When data from all the athletes were combined, energy deficits were positively correlated with body fat percentage, whereas energy surpluses were negatively correlated with body fat percentage. Similarly, the total hours with deficit kcals was positively correlated with body fat percentage, while the total hours with surplus kcals were negatively correlated with body fat percentage. It is also interesting to note that an energy surplus was (non-significantly) inversely associated with body fat percentage. In light of these findings, the authors concluded that athletes should not follow restrained or delayed eating patterns to achieve a desired body composition [50].

Iwao and colleagues [51] examined boxers who were subjected to a hypocaloric diet while either consuming two or six meals per day. The study lasted for two weeks and the participants consumed 1,200 kcals per day. At the conclusion of the study, overall weight loss was not significantly different between the groups [51]. However, individuals that consumed 6 meals per day had significantly less loss of lean body mass and urinary 3-methylhistidine/creatinine as opposed to those that only consumed two meals [51]. This would suggest that an increased meal frequency under hypocaloric conditions may have an anti-catabolic effect.

A published abstract by Benardot et al. [49] demonstrated that when a 250 calorie snack was given to 60 male and female college athletes for two weeks after breakfast, lunch, and dinner, as opposed to a non-caloric placebo, a significant amount of fat $(-1.03 \%)$ was lost and lean body mass $(+1.2 \mathrm{~kg})$ gained. Furthermore, a significant increase in anaerobic power and energy output was observed via a 30 -second Wingate test in those that consumed the 250 calorie snack [49]. Conversely, no significant changes were observed in those consuming the non-caloric placebo. Interestingly, when individuals consumed the total snacks of $750 \mathrm{kcals}$ a day, they only had a non-significant increase in total daily caloric consumption of $128 \mathrm{kcals}$ [49]. In other words, they concomitantly ate fewer calories at each meal. Lastly, when the $250 \mathrm{kcal}$ snacks were removed, the aforementioned values moved back to baseline levels 4 weeks later [49].

In conclusion, the small body of studies that utilized athletes as study participants demonstrated that increased meal frequency had the following benefits:

- suppression of lean body mass losses during a hypocaloric diet [51]

- significant increases in lean body mass and anaerobic power [49] (abstract)

- significant increases in fat loss [49] (abstract)

These trends indicate that if meal frequency improves body composition, it is likely to occur in an athletic population as opposed to a sedentary population. While no experimental studies have investigated why athletes may benefit more from increased meal frequency as compared to sedentary individuals, it may be due to the 
anabolic stimulus of exercise training and how ingested nutrients are partitioned throughout the body. It is also possible that a greater energy flux (intake and expenditure) leads to increased futile cycling, and over time, this has beneficial effects on body composition.

Even though the relationship between energy intake and frequency of eating has not been systematically studied in athletes, available data demonstrates that athletes (runners, swimmers, triathletes) follow a high meal frequency (ranging from 5 to 10 eating occasions) in their daily eating practices [85-88]. Such eating practices enable athletes to ingest a culturally normalized eating pattern (breakfast, lunch, and dinner), but also enable them to adhere to the principles of nutrient timing (i.e., ingesting carbohydrate and protein nutrients in the time periods before and immediately following physical activity/competition).

\section{Conclusion}

Like many areas of nutritional science, there is no universal consensus regarding the effects of meal frequency on body composition, body weight, markers of health, markers of metabolism, nitrogen retention, or satiety. The equivocal outcomes of the studies that have examined the relationship between meal frequency and body composition may be attributed to under-reporting of food intake (especially in overweight or obese individuals), the various ages of participants, and whether or not exercise/ physical activity was accounted for in the analysis. Furthermore, it has been pointed out by Ruidavets et al. [17] that the various ways a meal versus a snack is defined may lead to a different classification of study participants and ultimately influence the outcome of a study. Equally important, calculating actual meal frequency, especially in free-living studies, depends on the time between meals, referred to as "time lag", and may also influence study findings [17]. Social and cultural definitions of an actual "meal" (vs. snack) vary greatly and time between "meals" is arbitrary [17]. In other words, if the "time-lag" is very short, it may increase the number of feedings as opposed to a study with a greater "time-lag" [17]. Thus, all of these potential variables must be considered when attempting to establish an overall opinion on the effects of meal frequency on body composition, markers of health, various aspect of metabolism, and satiety. Taking all of this into account, it appears from the existing (albeit limited) body of research that increased meal frequency may not play a significant role in weight loss/gain when under-reporting, restrained eating, and exercise are accounted for in the statistical analyses. Furthermore, most, but not all of the existing research, fails to support the effectiveness of increased meal frequency on the thermic effect of food, resting metabolic rate, and total energy expenditure. However, when energy intake is limited, increased meal frequency may likely decrease hunger, decrease nitrogen loss, improve lipid oxidation, and improve blood markers such as total and LDL cholesterol, and insulin. Nonetheless, more welldesigned research studies involving various meal frequencies, particularly in physically active/athletic populations are warranted.

\section{Author details}

'Dept. of Health, Human Performance and Recreation, Baylor University, Waco, TX, USA. ${ }^{2}$ School of Physical Education and Exercise Science, University of South Florida, Tampa, FL, USA. ${ }^{3}$ Department of Exercise Science and Sports Studies, The University of Tampa, Tampa, FL, USA. ${ }^{4}$ Dept. of Exercise and Nutrition Sciences, University at Buffalo, Buffalo, NY, USA.

${ }^{5}$ Precision Nutrition Inc., Toronto, ON Canada. ${ }^{6}$ High Performance Nutrition, Mercer Island, WA, USA. ${ }^{7}$ Department of Health and Kinesiology, Texas A \& M University, College Station, TX, USA. ${ }^{8}$ The University of Oklahoma, Norman, OK, USA. ${ }^{9}$ The Center for Applied Health Sciences, Stow, Ohio, USA. ${ }^{10}$ Spano Sports Nutrition Consulting, Atlanta, GA, USA. " ${ }^{11}$ epartment of Exercise Science and Biology, Nova Southeastern University, Fort Lauderdale, FL, USA.

\section{Authors' contributions}

All authors read and extensively reviewed and contributed to the final manuscript.

\section{Competing interests}

The authors declare that they have no competing interests.

Received: 18 February 2011 Accepted: 16 March 2011 Published: 16 March 2011

\section{References}

1. Hedley AA, Ogden CL, Johnson CL, Carroll MD, Curtin LR, Flegal KM: Prevalence of overweight, obesity among US children, adolescents, and adults, 1999-2002. Jama 2004, 291(23):2847-50.

2. Howarth NC, Huang TT, Roberts SB, Lin BH, McCrory MA: Eating patterns and dietary composition in relation to $\mathrm{BMI}$ in younger and older adults. Int J Obes (Lond) 2007, 31(4):675-84.

3. De Castro JM: Socio-cultural determinants of meal size and frequency. $\mathrm{Br}$ J Nutr 1997, 77(Suppl 1):S39-54, discussion S54-5.

4. de Castro JM: Behavioral genetics of food intake regulation in free-living humans. Nutrition 1999, 15(7-8):550-4.

5. Gwinup G, Kruger FA, Hamwi GJ: Metabolic Effects of Gorging Versus Nibbling. Ohio State Med J 1964, 60:663-6.

6. Longnecker MP, Harper JM, Kim S: Eating frequency in the Nationwide Food Consumption Survey (U.S.A.), 1987-1988. Appetite 1997, 29(1):55-9.

7. Verboeket-van de Venne WP, Westerterp KR: Influence of the feeding frequency on nutrient utilization in man: consequences for energy metabolism. Eur J Clin Nutr 1991, 45(3):161-9.

8. Mattson MP: The need for controlled studies of the effects of meal frequency on health. Lancet 2005, 365(9475):1978-80.

9. Cohn C, Joseph D: Changes in body composition attendant on force feeding. Am J Physiol 1959, 196(5):965-8.

10. Cohn C, Shrago E, Joseph D: Effect of food administration on weight gains and body composition of normal and adrenalectomized rats. Am J Physiol 1955, 180(3):503-7.

11. Heggeness FW: Effect of Intermittent Food Restriction on Growth, Food Utilization and Body Composition of the Rat. J Nutr 1965, 86:265-70

12. Hollifield G, Parson W: Metabolic adaptations to a "stuff and starve" feeding program. II. Obesity and the persistence of adaptive changes in adipose tissue and liver occurring in rats limited to a short daily feeding period. J Clin Invest 1962, 41:250-3.

13. Fabry P, Hejl Z, Fodor J, Braun T, Zvolankova K: The Frequency of Meals. Its Relation to Overweight, Hypercholesterolaemia, and Decreased Glucose-Tolerance. Lancet 1964, 2(7360):614-5.

14. Hejda S, Fabry P: Frequency of Food Intake in Relation to Some Parameters of the Nutritional Status. Nutr Dieta Eur Rev Nutr Diet 1964, 64:216-28 
15. Metzner HL, Lamphiear DE, Wheeler NC, Larkin FA: The relationship between frequency of eating and adiposity in adult men and women in the Tecumseh Community Health Study. Am J Clin Nutr 1977, 30(5):712-5.

16. Drummond SE, Crombie NE, Cursiter MC, Kirk TR: Evidence that eating frequency is inversely related to body weight status in male, but not female, non-obese adults reporting valid dietary intakes. Int J Obes Relat Metab Disord 1998, 22(2):105-12.

17. Ruidavets JB, Bongard $V$, Bataille $V$, Gourdy $P$, Ferrieres J: Eating frequency and body fatness in middle-aged men. Int J Obes Relat Metab Disord 2002, 26(11):1476-83.

18. Ma Y, Bertone ER, Stanek EJ, Reed GW, Herbert JR, Cohen NL, Merriam PA, Ockene IS: Association between eating patterns and obesity in a freeliving US adult population. Am J Epidemiol 2003, 158(1):85-92.

19. Franko DL, Striegel-Moore RH, Thompson D, Affenito SG, Schreiber GB, Daniels SR, Crawford PB: The relationship between meal frequency and body mass index in black and white adolescent girls: more is less. Int J Obes (Lond) 2008, 32(1):23-9.

20. Dreon DM, Frey-Hewitt B, Ellsworth N, Williams PT, Terry RB, Wood PD: Dietary fat:carbohydrate ratio and obesity in middle-aged men. Am J Clin Nutr 1988, 47(6):995-1000.

21. Kant AK, Schatzkin A, Graubard BI, Ballard-Barbach R: Frequency of eating occasions and weight change in the NHANES I Epidemiologic Follow-up Study. Int J Obes Relat Metab Disord 1995, 19(7):468-74.

22. Summerbell CD, Moody RC, Shanks J, Stock MJ, Geissler C: Relationship between feeding pattern and body mass index in 220 free-living people in four age groups. Eur J Clin Nutr 1996, 50(8):513-9.

23. Andersson I, Rossner S: Meal patterns in obese and normal weight men: the 'Gustaf' study. Eur J Clin Nutr 1996, 50(10):639-46.

24. Crawley $\mathrm{H}$, Summerbell $\mathrm{C}$ : Feeding frequency and BMI among teenagers aged 16-17 years. Int J Obes Relat Metab Disord 1997, 21(2):159-61.

25. Titan SM, Welch A, Luben R, Oakes S, Day N, Khaw KT: Frequency of eating and concentrations of serum cholesterol in the Norfolk population of the European prospective investigation into cancer (EPIC-Norfolk): cross sectional study. Bmj 2001, 323(7324):1286-8.

26. Berteus Forslund $H$, Lindroos AK, Sjöström L, Lissner L: Meal patterns and obesity in Swedish women-a simple instrument describing usual meal types, frequency and temporal distribution. Eur J Clin Nutr 2002, 56(8):740-7.

27. Pearcey SM, de Castro JM: Food intake and meal patterns of weightstable and weight-gaining persons. Am J Clin Nutr 2002, 76(1):107-12.

28. Yannakoulia M, Melistas L, Solomou E, Yiannakouris N: Association of eating frequency with body fatness in pre- and postmenopausal women. Obesity (Silver Spring) 2007, 15(1):100-6.

29. Duval K, Strychar I, Cyr MJ, Prudhomme D, Rabasa-Lhoret R, Doucet E: Physical activity is a confounding factor of the relation between eating frequency and body composition. Am J Clin Nutr 2008, 88(5):1200-5.

30. Bandini $L G$, Schoeller DA, Cyr HN, Dietz WH: Validity of reported energy intake in obese and nonobese adolescents. Am J Clin Nutr 1990, 52(3):421-5.

31. Black $A E$, Prentice AM, Goldberg GR, Jebb SA, Bingham SA, Livingstone MB, Coward WA: Measurements of total energy expenditure provide insights into the validity of dietary measurements of energy intake. J Am Diet Assoc 1993, 93(5):572-9.

32. Braam LA, Ocke MC, Bueno-be-Mesquita HB, Seidell JC: Determinants of obesity-related underreporting of energy intake. Am J Epidemiol 1998, 147(11):1081-6.

33. Heitmann BL, Lissner L: Dietary underreporting by obese individuals-is it specific or non-specific? Bmj 1995, 311(7011):986-9.

34. Prentice AM, Black AE, Coward WA, davies HL, Goldberg GR, Murgatroyd PR, Ashford J, Sawyer M, Whitehead RG: High levels of energy expenditure in obese women. Br Med J (Clin Res Ed) 1986, 292(6526):983-7.

35. Schoeller DA, Bandini LG, Dietz WH: Inaccuracies in self-reported intake identified by comparison with the doubly labelled water method. Can J Physiol Pharmacol 1990, 68(7):941-9.

36. Tomoyasu NJ, Toth MJ, Poehlman ET: Misreporting of total energy intake in older men and women. J Am Geriatr Soc 1999, 47(6):710-5.

37. Bellisle F, McDevitt R, Prentice AM: Meal frequency and energy balance. $\mathrm{Br}$ J Nutr 1997, 77(Suppl 1):S57-70

38. Bortz WM, Wroldsen A, Issekutz B Jr, Rodahl K: Weight loss and frequency of feeding. N Engl J Med 1966, 274(7):376-9.
39. Finkelstein B, Fryer BA: Meal frequency and weight reduction of young women. Am J Clin Nutr 1971, 24(4):465-8.

40. Garrow JS, Durrant M, Blaza S, Wilkins D, Royston P, Sunkin S: The effect of meal frequency and protein concentration on the composition of the weight lost by obese subjects. Br J Nutr 1981, 45(1):5-15.

41. Verboeket-van de Venne WP, Westerterp KR: Frequency of feeding, weight reduction and energy metabolism. Int J Obes Relat Metab Disord 1993, 17(1):31-6.

42. Young CM, Scanlan SS, Topping CM, Simko V, Lutwak L: Frequency of feeding, weight reduction, and body composition. J Am Diet Assoc 1971, 59(5):466-72.

43. Cameron JD, Cyr MJ, Doucet E: Increased meal frequency does not promote greater weight loss in subjects who were prescribed an 8-week equi-energetic energy-restricted diet. Br J Nutr 2010, 103(8):1098-101.

44. Farshchi HR, Taylor MA, Macdonald IA: Decreased thermic effect of food after an irregular compared with a regular meal pattern in healthy lean women. Int J Obes Relat Metab Disord 2004, 28(5):653-60.

45. Stote KS, Baer DJ, Spears K, Paul DR, Harris GK, Rumpler W, Strycula P, Najjar SS, Ferrucci L, Ingram DK, Longo DL, Mattson MP: A controlled trial of reduced meal frequency without caloric restriction in healthy, normal-weight, middle-aged adults. Am J Clin Nutr 2007, 85(4):981-8.

46. Swindells YE, Holmes SA, Robinson MF: The metabolic response of young women to changes in the frequency of meals. Br J Nutr 1968, 22(4):667-80.

47. Wolfram G, Kirchgessner M, Müller HL, Hollomey S: Thermogenesis in humans after varying meal time frequency. Ann Nutr Metab 1987, 31(2):88-97.

48. Fabry P, Hejda S, Cerny K, Osancova K, Pechar J: Effect of meal frequency in schoolchildren. Changes in weight-height proportion and skinfold thickness. Am J Clin Nutr 1966, 18(5):358-61.

49. Benardot D, Martin DE, Thompson WR, Roman SB: Between-meal energy intake effects on body composition, performance, and total caloric consumption in athletes. Medicine and Science in Sports and Exercise 2005, 37(5):S339.

50. Deutz RC, Benardot D, Martin DE, Cody MM: Relationship between energy deficits and body composition in elite female gymnasts and runners. Med Sci Sports Exerc 2000, 32(3):659-68.

51. Iwao S, Mori K, Sato Y: Effects of meal frequency on body composition during weight control in boxers. Scand J Med Sci Sports 1996, 6(5):265-72.

52. Aspnes LE, Lee CM, Weindruch R, Chung SS, Roecker EB, Aiken JM: Caloric restriction reduces fiber loss and mitochondrial abnormalities in aged rat muscle. Faseb J 1997, 11(7):573-81.

53. Martin B, Golden E, Carlson OD, Egan JM, Egan JM, Mattson MP Maudsley S: Caloric restriction: impact upon pituitary function and reproduction. Ageing Res Rev 2008, 7(3):209-24.

54. Weindruch $\mathrm{R}$ : The retardation of aging by caloric restriction: studies in rodents and primates. Toxicol Pathol 1996, 24(6):742-5.

55. Fontana L, Meyer TE, Klein S, Holloszy JO: Long-term calorie restriction is highly effective in reducing the risk for atherosclerosis in humans. Proc Natl Acad Sci USA 2004, 101(17):6659-63.

56. Gwinup G, Byron RC, Rouch W, Kruger F, Hamwi GJ: Effect of nibbling versus gorging on glucose tolerance. Lancet 1963, 2(7300):165-7.

57. Gwinup G, Byron RC, Rouch WH, Kruger FA, Hamwi GJ: Effect of Nibbling Versus Gorging on Serum Lipids in Man. Am J Clin Nutr 1963, 13:209-13.

58. Kudlicka V, Fabry P, Dobersky P, Kudlickova V: Nibbling versus Meal Eating in the Treatment of Obesity. Proceedings of the Seventh International Congress of Nutrition, Hamburg 1966, 2:246.

59. Jenkins DJ, Wolever TM, Vuksan V, Brighenti F, Cunnane SC, Rao AV, Jenkins AL, Buckley G, Pattern R, Singer W: Nibbling versus gorging: metabolic advantages of increased meal frequency. N Engl J Med 1989, 321(14):929-34.

60. Edelstein SL, Barrett-Connor EL, Wingard DL, Cohn BA: Increased meal frequency associated with decreased cholesterol concentrations; Rancho Bernardo, CA, 1984-1987. Am J Clin Nutr 1992, 55(3):664-9.

61. LeBlanc J, Mercier I, Nadeau A: Components of postprandial thermogenesis in relation to meal frequency in humans. Can J Physio Pharmacol 1993, 71(12):879-83.

62. Jagannathan SN, Connell WF, Beveridge JM: Effects of Gormandizing and Semicontinuous Eating of Equicaloric Amounts of Formula-Type High Fat Diets on Plasma Cholesterol and Triglyceride Levels in Human Volunteer Subjects. Am J Clin Nutr 1964, 15:90-3. 
63. Irwin MI, Feeley RM: Frequency and size of meals and serum lipids, nitrogen and mineral retention, fat digestibility, and urinary thiamine and riboflavin in young women. Am J Clin Nutr 1967, 20(8):816-24.

64. Mann J: Meal frequency and plasma lipids and lipoproteins. Br J Nutr 1997, 77(Suppl 1):S83-90

65. Kinabo $J \mathrm{~L}$, Durnin $\mathrm{JV}$ : Effect of meal frequency on the thermic effect of food in women. Eur J Clin Nutr 1990, 44(5):389-95.

66. Tai MM, Castillo P, Pi-Sunyer FX: Meal size and frequency: effect on the thermic effect of food. Am J Clin Nutr 1991, 54(5):783-7.

67. Molnar D: The effect of meal frequency on postprandial thermogenesis in obese children. Padiatr Padol 1992, 27(6):177-81.

68. Smeets AJ, Westerterp-Plantenga MS: Acute effects on metabolism and appetite profile of one meal difference in the lower range of meal frequency. Br J Nutr 2008, 99(6):1316-21.

69. Taylor MA, Garrow JS: Compared with nibbling, neither gorging nor a morning fast affect short-term energy balance in obese patients in a chamber calorimeter. Int J Obes Relat Metab Disord 2001, 25(4):519-28.

70. Verboeket-van de Venne WP, Westerterp KR, Kester AD: Effect of the pattern of food intake on human energy metabolism. Br J Nutr 1993, 70(1):103-15.

71. Dangin M, Guillet C, Garcia-Rodenas C, Gachon P, Bouteloup-Demange C, Reiffers-Magnani K, Fauquant J, Beaufrere B: The rate of protein digestion affects protein gain differently during aging in humans. J Physio/ 2003, 549(Pt 2):635-44.

72. Moore DR, Robinson MJ, Fry JL, Tang JE, Glover El, Wilkinson SB, Prior T, Tarnopolsky MA, Phillips SM: Ingested protein dose response of muscle and albumin protein synthesis after resistance exercise in young men. Am J Clin Nutr 2009, 89(1):161-8.

73. Bohe J, Low A, Wolfe RR, Rennie MJ: Human muscle protein synthesis is modulated by extracellular, not intramuscular amino acid availability: a dose-response study. J Physiol 2003, 552(Pt 1):315-24.

74. What We Eat in America, NHANES 2007-2008. 2008 [http://www.ars.usda. gov/SP2UserFiles/Place/12355000/pdf/0708/tables_1-36_2007-2008.pdf].

75. Wilson GJ, Norton LE, Moulton CJ, Rupassara I, Garlick PJ, Layman DK: Equal distributions of dietary protein throughout the day maximizes rat skeletal muscle mass. The FASEB Journal 2010, 24(740.17)

76. Paddon-Jones D, Sheffield-Moore M, Aarsland A, Wolfe RR, Ferrando AA: Exogenous amino acids stimulate human muscle anabolism without interfering with the response to mixed meal ingestion. Am J Physiol Endocrinol Metab 2005, 288(4):E761-7.

77. Campbell B, Kreider RB, Ziegenfuss T, La Bounty P, Roberts M, Burke D, Landis J, Lopez H, Antonio J: International Society of Sports Nutrition position stand: protein and exercise. J Int Soc Sports Nutr 2007, 4:8.

78. Kerksick C, Harvey T, Stout J, Campbell B, Wilborn C, Kreider R, Kalman D, Ziegenfuss T, Lopez H, Landis J, Ivy JL, Antonio J: International Society of Sports Nutrition position stand: nutrient timing. J Int Soc Sports Nutr 2008, $5: 17$.

79. Blundell JE, Green S, Burley V: Carbohydrates and human appetite. Am J Clin Nutr 1994, 59(3 Suppl):728S-734S.

80. Prentice AM, Poppitt SD: Importance of energy density and macronutrients in the regulation of energy intake. Int J Obes Relat Metab Disord 1996, 20(Suppl 2):S18-23.

81. Rolls BJ, Castellanos VH, Halford JC, Kilara A, Panyam D, Pelkman CL, Smith GP, Thorwart ML: Volume of food consumed affects satiety in men. Am J Clin Nutr 1998, 67(6):1170-7.

82. Rolls $B J$, Hetherington $M$, Burley $V J$ : The specificity of satiety: the influence of foods of different macronutrient content on the development of satiety. Physiol Behav 1988, 43(2):145-53.

83. Speechly DP, Rogers GG, Buffenstein R: Acute appetite reduction associated with an increased frequency of eating in obese males. Int J Obes Relat Metab Disord 1999, 23(11):1151-9.

84. Speechly DP, Buffenstein R: Greater appetite control associated with an increased frequency of eating in lean males. Appetite 1999, 33(3):285-97.

85. Burke LM, Gollan RA, Read RS: Dietary intakes and food use of groups of elite Australian male athletes. Int J Sport Nutr 1991, 1(4):378-94.

86. Hawley JA, Burke LM: Effect of meal frequency and timing on physical performance. Br J Nutr 1997, 77(Suppl 1):S91-103.

87. Hawley JA, Williams MM: Dietary intakes of age-group swimmers. $\mathrm{Br} J$ Sports Med 1991, 25(3):154-8.

88. Lindeman AK: Eating and training habits of triathletes: a balancing act. $J$ Am Diet Assoc 1990, 90(7):993-5. doi:10.1186/1550-2783-8-4

Cite this article as: La Bounty et al.: International Society of Sports Nutrition position stand: meal frequency. Journal of the International Society of Sports Nutrition 2011 8:4.

\section{Submit your next manuscript to BioMed Central and take full advantage of:}

- Convenient online submission

- Thorough peer review

- No space constraints or color figure charges

- Immediate publication on acceptance

- Inclusion in PubMed, CAS, Scopus and Google Scholar

- Research which is freely available for redistribution

Submit your manuscript at www.biomedcentral.com/submit
Biomed Central 